\title{
OS MARCOS NORMATIVOS DA MEDIAÇÃO ENTRE PARTICULARES NO ÂMBITO CIVIL: ESCOPO E RELAÇÕES DE COMPLEMENTARIEDADE, SUBSIDIARIEDADE E INCOMPATIBILIDADE
}

\author{
Danilo Christiano Antunes Meira \\ Doutorando em Direito pela UFSC. Mestre em Direito pela \\ UFSC. Graduado em Direito pela FADISA. Membro do \\ grupo de pesquisa NECODI - Núcleo de Estudos Conhecer \\ Direito (IMED/Passo Fundo). Bolsista CNPq. \\ danchristiano@gmail.com
}

\section{Horácio Wanderlei Rodrigues}

Doutor em Direito (Filosofia do Direito e da Política) pela Universidade Federal de Santa Catarina (UFSC). Mestre em Direito (Instituições Jurídico-Políticas) pela UFSC. Realizou Estágios de Pós-Doutorado em Filosofia na Universidade do Vale do Rio dos Sinos (UNISINOS) e em Educação na Universidade Federal do Rio Grande do Sul (UFRGS). Professor Permanente do Programa de PósGraduação em Direito (PPG Direito) da Faculdade Meridional (IMED/RS). Professor Colaborador do Programa de Pós-Graduação em Direito (PPGD) da UFSC. Professor Titular de Teoria do Processo do Departamento de Direito da UFSC, de 1994 a 2016. Coordenador do Mestrado Profissional em Direito em Direito da UFSC, de 2015 a 2016. Sócio fundador do Conselho Nacional de Pesquisa e Pós-Graduação em Direito (CONPEDI) e da Associação Brasileira de Ensino do Direito (ABEDi). Membro do Instituto Iberomericano de Derecho Procesal (IIDP). Pesquisador do Conselho Nacional de Desenvolvimento Científico e Tecnológico (CNPq) e da Fundação Meridional. Presidente da Comissão de Educação Jurídica da $\mathrm{OAB} / \mathrm{SC}$. Publicou diversos livros e uma centena de artigos em coletâneas e revistas especializadas, em especial sobre Ensino e Pesquisa em Direito, Direitos Humanos e Teoria do Processo.

horaciowr@gmail.com

RESUMO: O presente artigo oferece uma análise da vigência dos marcos normativos da mediação entre particulares. No tópico 2 são apresentadas as normas que disciplinam a mediação e os seus respectivos escopos. São apresentadas a Resolução no 125/2010 do CNJ, o Código de Processo Civil e a Lei da Mediação. No tópico 3 é promovida uma verificação das possibilidades de incidência das disposições de cada um dos marcos normativos a partir de critérios de resolução de antinomias. Argumenta-se que a Resolução no 125/2010 do CNJ tem uma incidência limitada e subsidiária. Argumenta-se que a Lei da Mediação tem primazia em face do Código de Processo Civil, mas o revoga apenas quando confere disciplina expressamente incompatível. O tópico 4 é

Recebido em: 4 nov. 2016. Avaliado em: 20 e 26 nov. 2016. 
Os marcos normativos da mediação entre particulares no âmbito civil: escopo e relações de complementariedade, subsidiariedade e incompatibilidade

dedicado à análise de elementos afetados pelos problemas de incompatibilidade, como a definição, princípios, obrigatoriedade, impedimentos do mediador e obrigatoriedade de advogado. Conclui-se que existem problemas concretos derivados de atividade legislativa ineficiente, mas que outros problemas são derivados de interpretações equivocadas. Conclui-se que os problemas concretos derivados de atividade legislativa ineficiente só podem ser superados pela prática jurídica ou pelo próprio legislador.

PALAVRAS-CHAVE: Mediação entre particulares; Marcos normativos; Incompatibilidades.

\section{The regulatory frameworks for mediation between particulars in the civil framework: scope and complementarity, subsidiarity and incompatibility relationships}

ABSTRACT: This article offers an analysis of the effectiveness of the mediation's legal framework. The laws governing mediation and their respective scopes are analyzed in the topic 2. Are presented the Resolution N. ${ }^{\circ}$ 125/2010 of the CNJ, the Civil Procedure Code and the Mediation Law. The application possibilities of these regulatory frameworks will be checked in topic 3 from antinomies resolution criteria. It is argued that Resolution $N .^{\circ} 125 / 2010$ of the CNJ has a limited impact and subsidiary. It is argued that the Mediation Law prevails in the face of the Civil Procedure Code but it revokes only when its rules are explicitly incompatible. The topic 4 is dedicated to the analysis of elements affected by incompatibility issues as the definition, principles, obligatoriness, mediator impediments and obligation to have a lawyer. It concludes that there are real problems derived from inefficient legislative activity, while other problems are derived from misinterpretations. It concludes that the real problems that are derived from inefficient legislative activity can only be overcome by legal practice or by the legislature.

KEYWORDS: Mediation between individuals; Regulatory frameworks; Incompatibilities.

\section{INTRODUÇÃO}

A mediação é um instituto que tem ganhado expressiva atenção da comunidade jurídica e do poder público. Não é arriscado afirmar que ela constitui um dos temas mais debatidos nos círculos jurídico e acadêmico. No entanto, a mediação não é um instituto propriamente novo no âmbito do Direito brasileiro. Sua prescrição já havia sido tipificada para certos casos e circunstâncias, como no Decreto ${ }^{\circ} 1.572 / 1995$, na Lei $n^{\circ} 10.101 / 2000$ e na Lei $n^{\circ} 10.192 / 2001$, embora ainda sem um procedimento definido. O Decreto $\mathrm{n}^{\circ}$ 1.572/1995 prevê expressamente a mediação como procedimento de negociação coletiva de natureza trabalhista quando frustrada a negociação direta ${ }^{1}$. É uma modalidade que conta inclusive com um sistema de negociações online denominado Mediador ${ }^{2}$. A Lei $n^{\circ} 10.101 / 2000$, por sua vez, dispõe sobre a participação dos trabalhadores nos lucros ou resultados da empresa e estabelece que os procedimentos de mediação e arbitragem podem ser utilizados pelas partes "caso a negociação visando à participação nos lucros ou resultados da empresa resulte em impasse" ". Na Lei no 10.192/2001, a mediação aparece como alternativa para superar impasses entre empregados e empregadores sobre o pagamento de reajuste salarial decorrente da implementação do Plano Real ${ }^{4}$. Além de ser prevista legalmente

\footnotetext{
1 Decreto $\mathrm{n}^{\mathrm{o}} 1.572 / 1995$, art. $2^{\mathrm{o}}$.

2 O sistema Mediador está disponível no endereço eletrônico <http://www3.mte.gov.br/sistemas/mediador/> e sua utilização subsidiada com um manual ilustrado. Ver MINISTÉRIO DO TRABALHO E EMPREGO. Secretaria de Relações do Trabalho - SRT. Cartilha do Mediador. Disponível em <http://www3.mte.gov.br/sistemas/mediador/Content/docs/CARTILHA DO MEDIADOR v20.pdf>. Acesso em: 10 de outubro de 2016.

3 Lei $\mathrm{n}^{\circ} 10.101 / 2000$, art. $4^{\mathrm{o}}$, caput e inc. I.

${ }^{4}$ Lei ${ }^{\circ} 10.192 / 2001$, arts. $9^{\circ}, 10$ e 11 .
} 
nessas hipóteses, a mediação também foi utilizada com considerável frequência como procedimento não tipificado em litígios levados aos Núcleos de Prática Jurídica de Instituições de Ensino Superior (RIBEIRO, 2008) e até mesmo ao judiciário ${ }^{5}$.

Considerando que o instituto em si não é tão novo como parece, a relevância e ares de novidade que a mediação vem ganhando são explicadas por duas outras razões. A primeira é que o Poder Público passou a promovê-la como estratégia para reduzir custos e o tempo de processamento de conflitos levados ao judiciário ${ }^{6}$. Não por coincidência o fortalecimento da mediação foi firmado como um dos compromissos do II Pacto Republicano de Estado por um sistema de justiça mais acessível, ágil e efetivo, assinado em 2009. Dentre os objetivos desse pacto, destacase o aprimoramento da "prestação jurisdicional, mormente pela efetividade do princípio constitucional da razoável duração do processo e pela prevenção de conflitos" (BRASIL, 2009). A segunda, uma consequência da primeira, é que o seu procedimento foi expressamente disciplinado e prescrito para conflitos de diversas naturezas entre particulares no âmbito civil, seja antes ou no curso de um processo judicial.

De fato, a aposta na mediação como forma de tornar a prestação jurisdicional mais eficiente e a tradução dessa aposta em termos normativos constituem questões que merecem atenção na atual conjuntura econômica e social. Todavia, a materialização da pretensão do Poder Público no instituto da mediação é especialmente relevante para a comunidade jurídica porque dá indícios de que foi prejudicada, ao menos parcialmente, por má técnica legislativa. É perceptível que uma das principais preocupações abordadas nos debates sobre a mediação é a interpretação ou a identificação correta dos dispositivos aplicáveis em uma dada instância da mediação. É o caso, por exemplo, de saber se a audiência de mediação é obrigatória e de saber quais são os impedimentos aos quais se submete o advogado que atua como mediador judicial. Existem opiniões divergentes sobre esses casos e, à primeira vista, existem fundamentos jurídicos que sustentam os dois lados dessa divergência.

Diante desse fato, torna-se necessário: (a) verificar se essas divergências são justificáveis ou se são apenas incompreensões superficiais e, caso existam divergências justificáveis, (b) saber como superá-las.

O presente artigo constitui-se em uma tentativa de responder essas questões. Para tanto, começa por uma análise das normas que disciplinam a mediação entre particulares para saber quais são os seus respectivos escopos, isto é, saber qual é a vocação e a abrangência de cada uma dessas normas na tarefa de disciplinar a mediação. Uma vez conhecido o escopo das normas que disciplinam a mediação, a análise segue para uma verificação das possibilidades de incidência das disposições de cada um dos marcos normativos a partir de critérios de resolução de antinomias. Isso significa que será necessário procurar as regras que disciplinam as relações recíprocas entre os marcos normativos para saber como proceder em casos de relações de subsidiariedade, complementariedade e incompatibilidade. Como a hipótese inicial é a de que existem as três relações simultaneamente (subsidiariedade, complementariedade e incompatibilidade), a análise passa para a ilustração de problemas supostamente derivados dessas relações, como aqueles que se referem a definição legal, aos princípios orientadores, ao caráter de obrigatoriedade da audiência, hipóteses de impedimento do mediador advogado e a obrigatoriedade de atuação de advogado ou defensor público como procuradores das partes. Caso as hipóteses iniciais se confirmem,

\footnotetext{
${ }^{5}$ O próprio Conselho Nacional de Justiça, ao justificar a edição da Resolução n ${ }^{\circ}$ 125/2010, reconhece a existência da mediação em programas que já estavam implementados. A propósito, outro fato que justificava a citada resolução era a necessidade de sistematizar e aprimorar as práticas de solução consensual de litígios utilizadas pelos tribunais (CNJ, 2010) .

${ }^{6}$ Cf. exposições de motivos da Resolução CNJ no 125/2010, do anteprojeto do Código de Processo Civil e da PLS no 517/2011, que é um dos projetos dos quais derivou a Lei da Mediação.
} 
Os marcos normativos da mediação entre particulares no âmbito civil: escopo e relações de complementariedade, subsidiariedade e incompatibilidade

conclui-se que existem problemas concretos derivados de atividade legislativa ineficiente, mas que outros problemas podem ser derivados de interpretações ou leituras equivocadas. Em relação à superação desses problemas, caso sejam derivados de má técnica legislativa, conclui-se só poderão ser superados pela prática jurídica ou pelo próprio legislador.

\section{O ESCOPO DAS NORMAS QUE DISCIPLINAM A MEDIAÇÃO}

Atualmente, a promoção e a disciplina da mediação entre particulares no âmbito civil são estabelecidas principalmente em três normas: a Resolução no 125/2010 do Conselho Nacional de Justiça, o Código de Processo Civil e a Lei da Mediação. Em tese, essas três normas deveriam funcionar em caráter de complementariedade plena. Deveriam ter espaços próprios de abrangência reciprocamente complementares, pois nenhuma revogou expressamente a outra e nem disciplinou inteiramente a matéria. Todavia, como será exposto a seguir, essa complementariedade é imperfeita. Aparentemente, os processos de discussão e elaboração da Resolução 125/2010, do Código de Processo Civil e da Lei de Mediação não ocorreram com a sincronização necessária, causando repetições e incompatibilidades que dificultam, em várias circunstâncias, a correta identificação dos dispositivos aplicáveis.

Diante desse fato, é preciso considerar os escopos dessas normas para, em seguida, perceber como é possível compreender os espaços de cada uma delas nessa instância normatividade plural e, por conseguinte, perceber as possíveis relações de subsidiariedade em soluções para os problemas derivados desse convívio. Em outras palavras, a correta localização dos dispositivos aplicáveis à mediação entre particulares no âmbito civil e suas respectivas interpretações depende, em primeiro lugar, da compreensão das propostas e da abrangência de cada uma das normas que disciplinam o procedimento.

\subsection{A Resolução CNJ nº 125/2010}

A Resolução CNJ n ${ }^{\circ} 125$ foi editada em 29 de novembro de 2010 durante a presidência do ex-Ministro César Peluso e passou por duas emendas - a Emenda $n^{\circ} 1$, de 31 de janeiro de 2013, e a Emenda ${ }^{\circ}$ 2, de 8 de março de 2016. Ela institui a Política Judiciária Nacional de tratamento adequado dos conflitos de interesses no âmbito do Poder Judiciário, cujo objetivo é "a assegurar a todos o direito à solução dos conflitos por meios adequados à sua natureza e peculiaridade"7.

O seu escopo é a regulamentação, organização e uniformização das atribuições institucionais para o oferecimento de mecanismos necessários à implementação dessa política em âmbito nacional, isto é, dos procedimentos alterativos para a solução de controvérsias e atendimento ao

7 Resolução CNJ nº 125/2010, art. $1^{\text {o }}$.

120 R. Jur. FA7, Fortaleza, v. 13, n. 2, p. 117-137, jul./dez. 2016 
cidadão $^{8}$. A ênfase é dada à mediação e à conciliação, mas não em caráter de exclusividade ${ }^{9}$. Na verdade, a resolução não traça nenhuma distinção específica entre mediação e conciliação. As matérias tratadas nos quatro capítulos, considerações finais e dois anexos ${ }^{10}$ da Resolução $n^{\circ}$ 125/2010 são bastante diversas. Encontram-se ali enunciados que versam desde atribuições institucionais até a localização apropriada dos espaços físicos para funcionar os procedimentos de solução de conflitos.

Muitas das disposições relativas ao âmbito estrutural da política refletem nitidamente o escopo da resolução, como a criação de Cadastro Nacional de Mediadores Judiciais e Conciliadores $^{11}$, do Sistema de Mediação e Conciliação Digital ${ }^{12}$, dos Núcleos Permanentes de Métodos Consensuais de Solução de Conflitos ${ }^{13}$, dos Centros Judiciários de Solução de Conflitos e Cidadania ${ }^{14}$ e das diretrizes curriculares para a capacitação de terceiros facilitadores (conciliadores e mediadores $)^{15}$. Todavia, a resolução também estabelece normas que afetam, mesmo que indiretamente, matérias de natureza procedimental. É o caso, por exemplo, da previsão de aplicação de regras de impedimento e suspeição para mediadores e conciliadores, inclusive quando membros das Câmaras Privadas de Conciliação ${ }^{16}$, e da instituição de um Código de Ética de Conciliadores e Mediadores Judiciais, que estabelece princípios e garantias da conciliação e mediação judiciais, regras que regem o procedimento de conciliação/mediação e previsões expressas de responsabilidades e sanções do conciliador/mediador ${ }^{17}$.

\subsection{O Código de Processo Civil}

A segunda norma a disciplinar a mediação foi o Código de Processo Civil, Lei $\mathrm{n}^{\circ}$ 13.105/2015. O escopo do Código de Processo Civil em si, obviamente, é o de estabelecer as

\footnotetext{
${ }^{8}$ Entre as justificativas apresentadas para a edição da Resolução CNJ n 125/2010, lê-se que "a eficiência operacional, o acesso ao sistema de Justiça e a responsabilidade social são objetivos estratégicos do Poder Judiciário, [...] que o direito de acesso à Justiça, previsto no art. $5^{\circ}, \mathrm{XXXV}$, da Constituição Federal além da vertente formal perante os órgãos judiciários, implica acesso à ordem jurídica justa, [...] que, por isso, cabe ao Judiciário estabelecer política pública de tratamento adequado dos problemas jurídicos e dos conflitos de interesses, que ocorrem em larga e crescente escala na sociedade, de forma a organizar, em âmbito nacional, não somente os serviços prestados nos processos judiciais, como também os que possam sê-lo mediante outros mecanismos de solução de conflitos, em especial dos consensuais, como a mediação e a conciliação", que é necessário "consolidar uma política pública permanente de incentivo e aperfeiçoamento dos mecanismos consensuais de solução de litígios", que "a conciliação e a mediação são instrumentos efetivos de pacificação social, solução e prevenção de litígios, e que a sua apropriada disciplina em programas já implementados no país tem reduzido a excessiva judicialização dos conflitos de interesses, a quantidade de recursos e de execução de sentenças", que é "imprescindível estimular, apoiar e difundir a sistematização e o aprimoramento das práticas já adotadas pelos tribunais", que "a relevância e a necessidade de organizar e uniformizar os serviços de conciliação, mediação e outros métodos consensuais de solução de conflitos, para lhes evitar disparidades de orientação e práticas, bem como para assegurar a boa execução da política pública, respeitadas as especificidades de cada segmento da Justiça" e que "a organização dos serviços de conciliação, mediação e outros métodos consensuais de solução de conflitos deve servir de princípio e base para a criação de Juízos de resolução alternativa de conflitos, verdadeiros órgãos judiciais especializados na matéria".

9 Estabelece a resolução, em seu art. $1^{\circ}$, parágrafo único, que "aos órgãos judiciários incumbe [...], antes da solução adjudicada mediante sentença, oferecer outros mecanismos de soluções de controvérsias, em especial os chamados meios consensuais, como a mediação e a conciliação, bem assim prestar atendimento e orientação ao cidadão".

${ }^{10}$ Eram quatro anexos no texto original. O Anexo II, que tratava dos Setores de Solução de Conflitos e Cidadania, e o Anexo IV, que tratava dos dados estatísticos, foram revogados pela Emenda n. 1 de 2013.

${ }^{11}$ Resolução CNJ n ${ }^{\circ} 125 / 2010$, art. 6º IX.

${ }^{12}$ Resolução CNJ n ${ }^{\circ} 125 / 2010$, art. 6 $6^{\circ}, \mathrm{X}$.

${ }^{13}$ Resolução CNJ n ${ }^{\circ} 125 / 2010$, art. $7^{\circ}$, caput.

${ }^{14}$ Resolução CNJ n ${ }^{\circ} 125 / 2010$, art. $8^{\circ}$, caput.

${ }^{15}$ Resolução CNJ no 125/2010, Anexo I.

${ }^{16}$ Resolução CNJ no ${ }^{\circ}$ 25/2010, art. $7^{\circ}, \S 6^{\circ}$.

${ }^{17}$ Resolução CNJ no 125/2010, Anexo III - Código de Ética de Conciliadores e Mediadores Judiciais.
} 
Os marcos normativos da mediação entre particulares no âmbito civil: escopo e relações de complementariedade, subsidiariedade e incompatibilidade

normas processuais civis e não apenas o procedimento da mediação. No entanto, é evidente que a mediação, ao lado da conciliação, ocupa um espaço privilegiado em seu texto. Ao contrário do Código de 1973, que vagamente indicava a possibilidade de o juiz tentar promover a conciliação das partes a qualquer tempo ${ }^{18}$, o Código de 2015 inseriu as palavras "mediação" e "mediador" 38 vezes $^{19}$ e 25 vezes $^{20}$, respectivamente, quase sempre acompanhadas das palavras "conciliação" e "conciliador". O tratamento conferido simultaneamente pelo Código de Processo Civil à mediação e à conciliação permite concluir que tais institutos se diferenciam, em tese, por apenas dois elementos básicos: o mediador atua preferencialmente quando houver vínculo anterior entre as partes e está impossibilitado de sugerir soluções aos litigantes ${ }^{21}$. De qualquer modo, as repetições indiferenciadas entre conciliação e mediação refletem bem o objetivo do legislador, que era o de "restringir o acesso ao judiciário [...] tendo em vista o valor maior, que é o judiciário poder trabalhar com mais tranquilidade" (SENADO FEDERAL, 2010) ${ }^{22}$. A restrição ao acesso ao judiciário é tipificada como dever de incentivo aos métodos consensuais de solução de litígios, entre os quais a mediação, e deve ser observado em qualquer momento processual ou até mesmo antes de sua instituição ${ }^{23}$.

Ultrapassada essa observação preliminar, é relevante perceber como a mediação está localizada topologicamente no Código de Processo Civil. Em primeiro lugar, destacam-se as já citadas disposições esparsas de incentivo à mediação. A primeira em capítulo sobre as normas fundamentais do processo $\mathrm{civil}^{24}$ e a segunda em capítulo sobre os poderes, deveres e responsabilidades do juiz ${ }^{25}$. Em segundo lugar, destacam-se as disposições sobre os conciliadores e mediadores judiciais, disciplinados entre os artigos 165 e 175. Entre os temas tratados encontramse desde o dever de os tribunais criarem centros judiciários de solução consensual de conflitos ${ }^{26}$ até critérios de cadastramento ${ }^{27}$ e hipóteses de impedimento ${ }^{28}$ e exclusão ${ }^{29}$ do mediador. Essas e outras disposições da mesma seção evidenciam uma questão que funciona como uma chave interpretativa básica de todas as demais: o legislador do Código de Processo Civil pretendeu disciplinar especialmente a mediação e conciliação judiciais. As figuras do conciliador e do mediador, a propósito, são tradadas no código como auxiliares da justiça ${ }^{30}$. Isso não significa, porém, que a sua disciplina não alcance procedimentos extrajudiciais. Além de trazer enunciados expressamente aplicáveis às câmaras privadas de mediação ${ }^{31}$, existe previsão de que os demais dispositivos da seção Dos Conciliadores e Mediadores Judiciais, "aplicam-se, no que couber, às

\footnotetext{
${ }^{18}$ Lei $^{\mathrm{o}} 5.869 / 1973$, art. 125 , IV.

${ }^{19}$ Código de Processo Civil, art. $3^{\circ}, \S 3^{\circ}$; art. 165 ; art. 166 , caput e $\S 2^{\circ}$; art. $166, \S 4^{\circ}$; art. 167 , caput e duas vezes no $\S 4^{\circ}$; art. 168; art. $169, \S 1^{\circ}$ e $\S 2^{\circ}$; art. 173, I, II e $\S 2^{\circ}$; art. 174; art. 175, caput e parágrafo único; art. 250, IV; art. 303, $\S 1^{\circ}$, II; art. 308, $\S 3^{\circ}$; art. 319, VII; título do Capítulo V; art. 334, caput e nos $\S \S 1^{\circ}, 2^{\circ}, 7^{\circ}$ e $12^{\circ}$; art. 335, I e II; art. 340 , $\S \S$ $3^{\circ}$ e $4^{\circ}$; art. 359; art. 565, caput e $\S 1^{\circ}$; art. 694, caput e parágrafo único; art. 695; e art. 696.

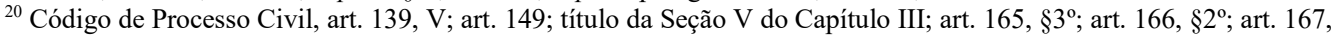
caput e $\S \S 1^{\circ}, 2^{\circ}, 3^{\circ}, 4^{\circ}, 5^{\circ}$ e $6^{\circ}$; art. 168 , caput e $\S \S 1^{\circ}, 2^{\circ}$ e $3^{\circ}$; art. 169; art. 170, caput e parágrafo único; art. 171; art. 172 ; art. 173 , caput e $\S 3^{\circ}$; art. $334, \S 1^{\circ}$; e art. 784 , IV.

${ }^{21}$ Código de Processo Civil, art. $165, \S \S 2^{\circ}$ e $3^{\circ}$.

${ }^{22} \mathrm{Na}$ ata da primeira reunião da comissão de juristas responsáveis pela elaboração do anteprojeto do Código de Processo Civil, a professora Tereza Wambier esclarece que "tendo em vista o valor maior, que é o judiciário poder trabalhar com mais tranquilidade e trabalhar, portanto, melhor. Então, eu só gostaria de fazer um apelo que a gente pensasse com mais intensidade numa forma eficiente de incentivar meios alternativos de resolução de conflitos" (SENADO FEDERAL, 2010).

${ }^{23}$ Código de Processo Civil, arts. $3^{\circ}, \S 3^{\circ}$ e $139, \mathrm{~V}$.

${ }^{24}$ Código de Processo Civil, art. $3^{\circ}, \S 3^{\circ}$.

${ }^{25}$ Código de Processo Civil, art. 139, V.

${ }^{26}$ Código de Processo Civil, art. 165.

${ }^{27}$ Código de Processo Civil, art. 167.

${ }^{28}$ Código de Processo Civil, art. $167, \S 5^{\circ}$.

${ }^{29}$ Código de Processo Civil, art. 173.

${ }^{30}$ Código de Processo Civil, art. 149.

${ }^{31}$ Código de Processo Civil, arts. 167, caput e $\S 3^{\circ}, 168$ e 169, $\S 2^{\circ}$.
} 
câmaras privadas de conciliação e mediação" 32 (BRASIL, 2015a). Por outro lado, as mesmas disposições da seção Dos Conciliadores e Mediadores Judiciais não excluem "outras formas de conciliação e mediação extrajudiciais vinculadas a órgãos institucionais ou realizadas por intermédio de profissionais independentes, que poderão ser regulamentadas por lei específica" (BRASIL, 2015a) ${ }^{33}$. Em terceiro lugar, destaca-se o tratamento conferido ao procedimento da audiência de conciliação e mediação do artigo 334 e seus parágrafos. Esses dispositivos disciplinam a forma de intimação para a audiência, o número de seções permitidas, hipóteses de não realização da audiência, a necessidade de acompanhamento de advogado ou defensor público e outras questões necessárias ao aperfeiçoamento do procedimento.

Existem muitas outras disposições espalhadas que poderiam ser citadas, mas as observadas no parágrafo anterior já evidenciam que o Código de Processo Civil cuidou tanto das disposições básicas de estrutura e organização institucional como do próprio procedimento, indicando as regras pelas quais os agentes devem ser conduzir. Em outras palavras, a mediação recebeu do Código de Processo Civil tratamento adequado o bastante para ser operacionalizada.

\subsection{A Lei da Mediação}

A Lei de Mediação, Lei $n^{\circ} 13.140 / 2015$, foi proposta originalmente na forma da PLS $n^{\circ}$ 517/2011 depois da publicação da Resolução $n^{\circ} 125 / 2010$ e durante a tramitação da PLS n ${ }^{\circ}$ 166/2010, da qual se originou o Código de Processo Civil. A compreensão do seu escopo é intuitivamente mais simples, pois ela é dedicada especificamente à disciplina de apenas dois institutos: a mediação entre particulares no âmbito civil e a autocomposição de conflitos no âmbito da administração pública.

À semelhança da Resolução no 125/2010 e do Código de Processo Civil, o propósito da Lei da Mediação é o de reduzir os custos e o tempo de processamento de litígios levados ao judiciário ${ }^{34}$. Para tanto, ela traz disposições que estabelecem desde o dever de criação de centros judiciários de solução consensual de $\operatorname{conflitos}^{35}$ até os critérios para a realização da primeira reunião de mediação extrajudicial prevista em cláusula contratual incompleta, como prazo, local e critérios de escolha do mediador ${ }^{36}$. Esses dois exemplos já dão indícios das principais aproximações e diferenças entre a Lei da Mediação e o Código de Processo Civil. As aproximações se mostram nas repetições de matérias que já estavam assentadas, como os princípios orientadores da mediação e as hipóteses de suspeição do mediador. $O$ enunciado que impõe aos tribunais o dever de criar os centros judiciários de solução consensual de conflitos é praticamente o mesmo nas duas leis ${ }^{37}$. Por outro lado, as diferenças entre a Lei da Mediação e o Código de Processo Civil na disciplina da mediação ocorrem de duas maneiras: algumas matérias são tratadas apenas em uma delas e outras matérias comum às duas são tratadas de forma diferente. A Lei da Medi-

\footnotetext{
${ }^{32}$ Código de Processo Civil, art. 175, parágrafo único.

${ }^{33}$ Código de Processo Civil, art. 175.

${ }^{34}$ Na justificação do PLS n ${ }^{\circ}$ 517/2011, o Senador Ricardo Ferraço, seu propositor, concebeu a mediação como um "instrumento capaz de incentivar outras formas de solução das pendências, de reduzir o número de processos judiciais e de combater o desvirtuamento da função judicial do Estado, conferindo, assim, uma leitura contemporânea do acesso à justiça previsto no art. 5, XXXV, da Constituição Federal do Brasil” (SENADO FEDERAL, 2011).

${ }^{35}$ Lei da Mediação, art. 24.

${ }^{36}$ Lei da Mediação, art. 22, § $2^{\circ}$.

${ }^{37}$ Ver art. 165 do Código de Processo Civil e art. 24 da Lei da Mediação. A diferença é que a Lei da Mediação atribui a tais centros a responsabilidade pela realização de audiências pré-processuais - e não apenas as processuais - de mediação
} 
Os marcos normativos da mediação entre particulares no âmbito civil: escopo e relações de complementariedade, subsidiariedade e incompatibilidade

ação deixa de lado, por exemplo, detalhes sobre a audiência de mediação, como o prazo de antecedência mínima para a citação do réu ${ }^{38}$, mas inclui dispositivos que regulamentam o procedimento no âmbito extrajudicial de forma claramente diferenciada. Como será exposto a seguir, essas diferenças deflagram alguns problemas que precisam ser evidenciados e superados. No momento, entretanto, importa apenas ressaltar a forma pela qual o escopo da Lei da Mediação se assemelha - mesmo que com algumas diferenças - ao escopo que o Código de Processo Civil reserva para a mediação.

\section{A RELAÇÃO DE SUBSIDIARIEDADE E COMPLEMENTARIEDADE DOS MARCOS NORMATIVOS EM FACE DA LINDB}

Como visto no tópico anterior, a Resolução ${ }^{\circ}$ 125/2010 do CNJ, o Código de Processo Civil e a Lei da Mediação concorrem simultaneamente na tarefa de disciplinar a mediação entre particulares no âmbito civil. A relação entre elas deveria ser de plena complementariedade, mas a ausência de uma adequada sintonia nos seus respectivos processos de elaboração desencadeou redundâncias e algumas antinomias.

No tópico anterior também foi demonstrado que a vocação de cada uma das normas converge para o mesmo propósito, mas demonstrou-se também que elas divergem em termos de matérias privilegiadas e em termos de abrangência. Isso torna claro que não é possível descartar, de plano, quaisquer delas sob a alegação de ocorrência de revogação integral tácita - e nem explícita, como notado, já que nenhuma trouxe tal previsão. Por outro lado, dado que uma mesma questão de fato não pode ter duas soluções jurídicas diferentes e simultaneamente válidas, é preciso verificar as formas pelas quais a Resolução CNJ nº 125/2010, o Código de Processo Civil e a Lei da Mediação podem se acomodar em relações de subsidiariedade e complementariedade.

\subsection{A incidência subsidiária e limitada da Resolução no ${ }^{0}$ 125/2010}

A Resolução $n^{0} 125 / 2010$ do CNJ é um ato regulamentar. Sua vinculatividade se restringe ao âmbito de competência do CNJ estabelecido no artigo 103-B, parágrafo $4^{\circ}$, da Constituição ${ }^{39}$. Desde a primeira vista, a propósito, o escopo da Resolução $\mathrm{n}^{\circ}$ 125/2010 parece ultrapassar a

\footnotetext{
${ }^{38}$ Ver art. 334 do Código de Processo Civil e art. 27 da Lei da Mediação.

${ }^{39} \S 4^{\circ}$ Compete ao Conselho o controle da atuação administrativa e financeira do Poder Judiciário e do cumprimento dos deveres funcionais dos juízes, cabendo-lhe, além de outras atribuições que lhe forem conferidas pelo Estatuto da Magistratura: I - zelar pela autonomia do Poder Judiciário e pelo cumprimento do Estatuto da Magistratura, podendo expedir atos regulamentares, no âmbito de sua competência, ou recomendar providências; II - zelar pela observância do art. 37 e apreciar, de ofício ou mediante provocação, a legalidade dos atos administrativos praticados por membros ou órgãos do Poder Judiciário, podendo desconstituí-los, revê-los ou fixar prazo para que se adotem as providências necessárias ao exato cumprimento da lei, sem prejuízo da competência do Tribunal de Contas da União; III - receber e conhecer das reclamações contra membros ou órgãos do Poder Judiciário, inclusive contra seus serviços auxiliares, serventias e órgãos prestadores de serviços notariais e de registro que atuem por delegação do poder público ou oficializados, sem prejuízo da competência disciplinar e correicional dos tribunais, podendo avocar processos disciplinares em curso e determinar a remoção, a disponibilidade ou a aposentadoria com subsídios ou proventos proporcionais ao tempo de serviço e aplicar outras sanções administrativas, assegurada ampla defesa; IV - representar ao Ministério Público, no caso de crime contra a administração pública ou de abuso de autoridade; V - rever, de ofício ou mediante provocação, os processos disciplinares de juízes e membros de tribunais julgados há menos de um ano; VI - elaborar semestralmente relatório estatístico sobre processos e sentenças prolatadas, por unidade da Federação, nos diferentes órgãos do Poder Judiciário; VII - elaborar relatório anual, propondo as providências que julgar necessárias, sobre a situação do Poder Judiciário no País e as atividades do Conselho, o qual deve integrar mensagem do Presidente do Supremo Tribunal Federal a ser remetida ao Congresso Nacional, por ocasião da abertura da sessão legislativa. (BRASIL, 1988)
} 
competência constitucional do CNJ, fato que poderia se somar aos vários debates acerca da nãoobservância dos limites das regulamentações editadas pelo CNJ (STRECK; SARLET; CLÈVE, 2005). Na medida em que se compreende a mediação e a conciliação como institutos de direito processual, é também possível questionar se a resolução não tenha afrontado até mesmo o próprio artigo 22 da Constituição ${ }^{40}$.

Para os objetivos do presente trabalho, porém, essas discussões não acrescentam informações relevantes. Basta a constatação de que a Resolução ${ }^{\circ}$ 125/2010 vinculará apenas aqueles que estejam subordinados ao $\mathrm{CNJ}$ e terão vigor apenas as suas disposições que não contrariarem o Código de Processo Civil e a Lei da Mediação, posto que atos regulamentares ocupam posição hierárquica inferior em relação às leis ordinárias ${ }^{41}$.

\subsection{A incidência do Código de Processo Civil e da Lei de Mediação}

As relações de subsidiariedade e complementariedade entre o Código de Processo Civil e a Lei da Mediação são mais delicadas. As duas são leis ordinárias de mesma hierarquia e devem ter suas antinomias resolvidas pela Lei de Introdução às Normas do Direito Brasileiro - LINDB, o Decreto-Lei n ${ }^{\circ}$ 4.657/1942. No caso, a compreensão das relações entre a Lei de Mediação e do Código de Processo civil deve ser alcançada especialmente pela incidência do artigo $2^{\circ}$, parágrafos $1^{\circ}$ e $2^{\circ}$ da LINDB.

$\mathrm{O}$ artigo $2^{\circ}$, parágrafo $1^{\circ}$, da Lei de Introdução às Normas do Direito Brasileiro estabelece que "a lei posterior revoga a anterior quando expressamente o declare, quando seja com ela incompatível ou quando regule inteiramente a matéria de que tratava a lei anterior". O artigo $2^{\circ}$, parágrafo $2^{\circ}$, da mesma lei prescreve que "a lei nova, que estabeleça disposições gerais ou especiais a par das já existentes, não revoga nem modifica a lei anterior”. A aplicação dessas disposições da LINDB, porém, não é isenta de controvérsia.

A primeira e principal questão surge da ausência de uma definição inequívoca das expressões "lei posterior" e "lei nova", cuja compreensão é pressuposto para a aplicação dos parágrafos $1^{\circ}$ e $2^{\circ}$ da Lei de Introdução às normas do Direito Brasileiro. É uma questão que pode ser ilustrada com uma simples pergunta: lei posterior (ou lei nova) é a lei publicada depois ou a lei que entrou em vigência depois? Essa indefinição tem como reflexo posicionamentos doutrinários divergentes na compreensão das relações de complementariedade, subsidiariedade e incompatibilidade entre o Código de Processo Civil e a Lei da Mediação. Enquanto alguns podem defender que a Lei da Mediação é posterior porque foi publicada depois do Código de Processo Civil, outros podem argumentar que o Código de Processo Civil pode ser considerado posterior porque ele entrou em vigência alguns meses depois da Lei da Mediação (TARTUCE, 2015). Nenhuma dessas duas compreensões pode ser desacreditada de plano. O Decreto-Lei n 4.657/1942 não estabelece explicitamente nem a data de publicação e nem a data de entrada em vigor como critério que identifica uma lei como posterior ou anterior para fins de resolução de antinomias. Trata-se de uma lacuna que os autores de literatura jurídica — a "doutrina" —, na qualidade de intérpretes inautênticos, não podem superar senão com opiniões não-vinculantes (KELSEN,

\footnotetext{
${ }^{40}$ Art. 22. Compete privativamente à União legislar sobre: I - direito civil, comercial, penal, processual, eleitoral, agrário, marítimo, aeronáutico, espacial e do trabalho; (BRASIL, 1988)

${ }^{41}$ Já se decidiu, por exemplo, pela ilegalidade de Resolução do CNJ que contrarie matéria procedimental estabelecida em lei federal e estadual, como no processo 5001014-88.2015.4.04.7103/JFRS (disponível em $<$ https://eproc.jfrs.jus.br/eprocV2/controlador.php?acao=acessar_documento_publico $\&$ doc $=711443016281284821500000000002 \&$ evento $=7114 \overline{4} 3016281284821500000000002 \& \mathrm{key}=\mathrm{ce} 445 \mathrm{ddbac} 2$ 3364c3ca53790ca580fc51bd8f213f6d6e6df90cfb092343516b4>).
} 
Os marcos normativos da mediação entre particulares no âmbito civil: escopo e relações de complementariedade, subsidiariedade e incompatibilidade

1998, p. 387-397). No caso concreto, a omissão será superada pelo aplicador do direito, o intérprete autêntico, talvez com o auxílio da própria LINDB, especificamente por seu artigo $4^{042}$.

A segunda questão surge da aplicação equivocada dos critérios de generalidade e de especialidade do artigo $2^{\circ}$, parágrafo $2^{\circ}$, da Lei de Introdução às normas do Direito Brasileiro, utilizados para justificar o primado da Lei da Mediação, considerada lei especial, sobre o Código de Processo Civil, considerado lei geral. Em primeiro lugar, o enunciado em questão não estabelece que a lei especial prevalece sobre a geral, ao contrário do que se costuma afirmar. $\mathrm{O}$ que o artigo $2^{\circ}$, parágrafo $2^{\circ}$, da LINDB considera geral ou especial são as disposições de uma lei e não as próprias leis. No caso da Lei da Mediação e do Código de Processo Civil, as duas trazem tanto disposições gerais e como especiais sobre a mediação. Algumas dessas disposições são exclusivas, isto é, são estabelecidas em apenas uma das leis. Em segundo lugar, os critérios de especialidade e generalidade são empregados no artigo $2^{\circ}$, parágrafo $2^{\circ}$, da LINDB apenas para enfatizar a hipótese de compatibilidade e complementariedade que o legislador pressupôs existir entre disposições de uma "lei nova" e "disposições [...] já estabelecidas". Nisso importa saber apenas qual é a lei nova e não qual lei contém disposições especiais ou gerais. Uma lei posterior com disposições gerais revogará lei anterior com disposições especiais caso as duas sejam incompatíveis. O que está em questão é: existindo compatibilidade, caso as novas disposições estejam "a par" das disposições já existentes, a lei anterior não será revogada ou modificada pela lei nova. Existindo incompatibilidade, a lei anterior será modificada ou revogada, sejam as suas disposições gerais ou especiais.

De toda sorte, ainda que esses impasses não possam ser resolvidos pelos autores do presente artigo, ainda é possível avançar na compreensão dos problemas relacionados à regulamentação da mediação a partir da LINDB.

Em relação à hipótese de revogação expressa, primeira parte do artigo. $2^{\circ}$, parágrafo $1^{\circ}$, da LINDB, parece não caber controvérsia. Como já notado ao longo deste artigo, o Código de Processo Civil não revogou (e nem poderia revogar) a ainda inexistente Lei da Mediação. A Lei da Mediação, por sua vez, também não revogou explicitamente as disposições do Código de Processo Civil. Em relação à hipótese de incompatibilidade, segunda parte do artigo $2^{\circ}$, parágrafo $1^{\circ}$, da LINDB, ela é confirmada parcialmente: algumas disposições são nitidamente incompatíveis, mas tal fato não justifica a revogação das outras disposições que complementares. Em relação à hipótese de regulamentação integral posterior, terceira parte do artigo $2^{\circ}$, parágrafo $1^{\circ}$, da LINDB, também ficou demonstrado que nem o Código de Processo Civil e nem a Lei da Mediação contemplam o instituto da mediação em sua integridade. Existem pontos só regulamentados pela Lei da Mediação e pontos só regulamentados pelo Código de Processo Civil. Por fim, em relação ao artigo $2^{\circ}, \S 2^{\circ}$, os tópicos anteriores demonstraram que existe um impasse quanto a definição de qual poderia ser considerada a lei nova (a Lei da Mediação por ter sido publicada depois ou o Código de Processo Civil por ter entrado em vigou depois) e a inexistência de uma relação de generalidade e especialidade plena (dado que ambas contêm disposições gerais e específicas).

Em face dessas questões, compartilhamos a opinião de que as disposições da Lei da Mediação prevalecem sobre as disposições do Código de Processo Civil porque entendemos que a expressão "lei nova" diz respeito ao plano de existência da norma e não ao pleno de eficácia. Do contrário, seria forçoso concluir que nenhuma lei promulgada para alterar outra não produziria efeitos caso entrasse em vigor antes dela. Todavia, entendemos também que as disposições do

${ }^{42}$ Art. $4^{\circ}$ Quando a lei for omissa, o juiz decidirá o caso de acordo com a analogia, os costumes e os princípios gerais de direito. (BRASIL, 1942) 
Código de Processo Civil são revogadas apenas naquilo que a Lei da Mediação contrariar expressamente, pois, por força do artigo $2^{\circ}, \S 2^{\circ}$, existe no caso uma presunção de complementariedade e não de revogação. As disposições relativas à conciliação do Código de Processo Civil, a propósito, seguem obviamente intactas.

\section{Problemas decorRentes de inCOMPATIBILIDADES}

As questões debatidas nos tópicos anteriores se justificam pela necessidade de perceber as causas de alguns problemas práticos decorrentes de incompatibilidades na disciplina simultânea que a mediação recebe da Resolução CNJ n ${ }^{\circ}$ 125/2010, do Código de Processo Civil e na Lei de Mediação. No presente tópico serão elencados, a título ilustrativo, apenas alguns desses problemas significativos e suas implicações. Certos problemas são quase irrelevantes e derivam apenas indiretamente das hipóteses de incompatibilidade, mas outros são diretamente derivados e podem impactar efetivamente o curso do procedimento. Dadas as limitações impostas à redação e apresentação de um único artigo, não seria possível apresentar e analisar todos os casos de incompatibilidade de modo satisfatório.

\subsection{A definição legal da mediação}

A análise dos conceitos legais de um instituto jurídico não é importante apenas para saber precisamente o que ele é, mas também para saber o que ele faz e como ele faz. Isso se explica porque, em várias circunstâncias, a definição legal determina a abrangência e outras características que disciplinam a sua operacionalização, além de estabelecer as linhas gerais pelas quais as outras normas procedimentais devem se orientar. Com o conceito legal de mediação ocorre justamente isso.

O Código de Processo Civil traz o conceito de mediação de forma indireta no artigo 165, $\S 3^{\circ}$. Pelo enunciado desse artigo é possível concluir que a mediação é um procedimento pelo qual um terceiro, o mediador, atuando "preferencialmente nos casos em que houver vínculo anterior entre as partes, auxiliará aos interessados a compreender as questões e os interesses em conflito, de modo que eles possam, pelo restabelecimento da comunicação, identificar, por si próprios, soluções consensuais que gerem benefícios mútuos" (BRASIL, 2015a). Esse conceito revela várias questões importantes sobre o procedimento. A primeira delas é que a mediação terá lugar preferencialmente em casos nos quais as partes tenham vínculos anteriores. A segunda é que o conceito limita o papel do terceiro facilitador - o mediador, a duas tarefas: promover o restabelecimento da comunicação entre as partes e auxiliá-las a compreender as questões e os interesses em conflito. A terceira é que são as próprias partes que identificam soluções consensuais. Por fim, o enunciado do artigo $165, \S 3^{\circ}$, combinado com o artigo $165, \S 2^{\circ}$, permite identificar os dois elementos básicos que distinguem a mediação da conciliação. O primeiro é que no procedimento da conciliação, ao contrário do que ocorre na mediação, o terceiro facilitador - o conciliador - “poderá sugerir soluções para o litígio, sendo vedada a utilização de qualquer tipo de constrangimento ou intimidação para que as partes conciliem"43 (BRASIL, 2015a). O segundo é que o conciliador atuará preferencialmente em conflitos nos quais as partes não tenham vínculo anterior.

A Lei da Mediação, a rigor, trouxe dois conceitos de mediação que se complementam um amplo e um estrito. Cada um deles tem uma relevância específica para a compreensão do

${ }^{43}$ Código de Processo Civil, art. 165, $\S 2^{\circ}$. 
Os marcos normativos da mediação entre particulares no âmbito civil: escopo e relações de complementariedade, subsidiariedade e incompatibilidade

instituto e para a sua operacionalização. O conceito amplo foi inscrito no caput do artigo $1^{\circ}$. Tal enunciado estabelece os objetivos da Lei de Mediação e, ao fazê-lo, demarca conceitualmente a mediação como "meio de solução de controvérsias entre particulares" "44 (BRASIL, 2015b). Essa definição ampla sugere duas conclusões. A primeira é que a expressão "meio de solução" parece atribuir à medição o status de procedimento diferenciado em relação aos procedimentos judiciais já tipificados, que seriam os procedimentos — ou "meios" — padrão para a solução de controvérsias. A segunda é que a definição revela que o termo "mediação" foi escolhido para identificar apenas procedimentos que solucionem conflitos entre particulares. A segunda parte do caput do artigo $1^{\circ}$, a propósito, demonstra que o legislador preferiu não definir como mediação a autocomposição de conflitos no âmbito da administração pública. O conceito estrito, por sua vez, é exposto no parágrafo único do mesmo artigo $1^{\circ}$. Esse dispositivo estabelece que a mediação é "a atividade técnica exercida por terceiro imparcial sem poder decisório, que, escolhido ou aceito pelas partes, as auxilia e estimula a identificar ou desenvolver soluções consensuais para a controvérsia"45 (BRASIL, 2015b). Esse enunciado não apenas confere mais clareza ao conceito jurídico de mediação, como também estabelece limites e exigências aos seus destinatários. Em primeiro lugar, o enunciado proíbe que o mediador atue com preferência por uma das partes. Em segundo lugar, proíbe que o mediador decida o conflito e imponha essa decisão às partes. O seu papel é expressamente limitado a estimular e auxiliar as partes na identificação ou desenvolvimento de soluções consensuais em termos que elas próprias devem estabelecer. Por fim, é interessante notar que o enunciado confere às partes o direito de escolher ou aceitar a pessoa que funcionará como mediador, mas essa escolha é paradoxalmente limitada pela incidência do artigo 25 , que estabelece que os mediadores não estarão sujeitos à prévia aceitação das partes na mediação judicial, ressalvadas as hipóteses de impedimento ${ }^{46}$.

À primeira vista, os conceitos de mediação trazidos pela Lei da Mediação e pelo Código de Processo Civil compartilham traços gerais que dão indícios de compatibilidade. São inclusive os mesmos que a literatura jurídica utiliza para caracterizar o instituto ${ }^{47}$. Todavia, das pequenas diferenças conceituais podem derivar alterações práticas relevantes. Em relação ao Código de Processo Civil, o conceito de mediação da Lei da Mediação implica uma restrição menor ao papel do mediador. Além de extinguir a preferência para atuar em casos nos quais as partes tenham vínculo anterior, o conceito da Lei da Mediação permite que o mediador auxilie as partes a desenvolver soluções consensuais. No Código de Processo Civil, como visto, o mediador poderia apenas auxiliá-las no reestabelecimento da comunicação e na compreensão das questões e dos interesses em conflito. De certo modo, essas duas implicações do conceito de mediação trazido pela Lei da Mediação parecem significar, em alguma medida, a fusão das figuras do mediador e do conciliador do Código de Processo Civil em uma só. A possibilidade de as partes

\footnotetext{
${ }^{44}$ Art. $1^{\text {o }}$ Esta Lei dispõe sobre a mediação como meio de solução de controvérsias entre particulares e sobre a autocomposição de conflitos no âmbito da administração pública" (grifos nossos).

${ }^{45}$ Lei da Mediação, art. $1^{\circ}$, parágrafo único.

${ }^{46}$ Art. 25. Na mediação judicial, os mediadores não estarão sujeitos à prévia aceitação das partes, observado o disposto no art. 5o desta Lei.

${ }^{47}$ Elpídio Donizetti (2016, tópico 4.2) concebe a mediação como "técnica de estímulo à autocomposição" na qual "um terceiro (mediador), munido de técnicas adequadas, ouvirá as partes e oferecerá diferentes abordagens e enfoques para o problema, aproximando os litigantes e facilitando a composição do litígio. A decisão caberá às partes, jamais ao mediador. A mediação assemelha-se à conciliação, uma vez que ambas visam à autocomposição. Dela se distingue somente porque a conciliação busca sobretudo o acordo entre as partes, enquanto a mediação objetiva debater o conflito, surgindo o acordo como mera consequência. Trata-se mais de uma diferença de método, mas o resultado acaba sendo o mesmo". Humberto Theodoro Jr. (2015, tópico 313) afirma que "a mediação consiste em facilitar o diálogo entre as partes, para que, assim, consigam pôr fim ao conflito de forma consensual. O mediador, terceiro imparcial e sem poder de decisão, por meio de técnicas de negociação, incentiva e auxilia os envolvidos a alcançar, por si próprios, uma solução pacífica e adequada ao problema por eles enfrentado".
} 
escolherem ou aceitarem o mediador extrajudicial não constitui diferença prática, pois tal possibilidade, embora ausente do conceito de mediação do Código de Processo Civil, é prevista em seu artigo $168^{48}$.

\subsection{Princípios orientadores da mediação}

Os princípios orientadores da mediação estão previstos nas três normas que a disciplinam. Ainda que eles sejam inter-relacionados, é necessário identificar a abrangência de cada um deles a partir da abrangência de suas respectivas normas.

A Lei da Mediação estabelece princípios que devem orientar a mediação judicial e a extrajudicial. Os princípios são a imparcialidade do mediador, a isonomia entre as partes, a oralidade, a informalidade, a autonomia da vontade das partes, a busca do consenso, a confidencialidade e a boa-fét ${ }^{49}$.

O Código de Processo Civil estabelece princípios que informam tanto a mediação como a conciliação. A localização topológica desses princípios parece sugerir que os mesmos foram concebidos para disciplinar os procedimentos que ocorrem no âmbito judicial ${ }^{50}$, inclusive porque as disposições da Seção V — Dos Conciliadores e Mediadores Judiciais "não excluem outras formas de conciliação e mediação extrajudiciais vinculadas a órgãos institucionais ou realizadas por intermédio de profissionais independentes, que poderão ser regulamentadas por lei específica" ${ }^{51}$ (BRASIL, 2015a). Todavia, o código também estabelece que as disposições da Seção V "aplicam-se, no que couber, às câmaras privadas de conciliação e mediação" 52 (BRASIL, 2015a). Por conseguinte, é de se concluir que "os princípios da independência, da imparcialidade, da autonomia da vontade, da confidencialidade, da oralidade, da informalidade e da decisão informada" ${ }^{33}$ (BRASIL, 2015a), previstos no Código de Processo Civil, são aplicáveis para a mediação judicial e, no que couber, para a extrajudicial.

A Resolução CNJ no 125/2010 traz em seu Anexo III o Código de Ética dos Conciliadores e Mediadores Judiciais. Nele estão estabelecidos os "princípios fundamentais que regem a atuação de conciliadores e mediadores judiciais", que seriam "confidencialidade, decisão informada, competência, imparcialidade, independência e autonomia, respeito à ordem pública e às leis vigentes, empoderamento e validação" 54 (BRASIL, 2010).

A distribuição dos princípios da mediação entre a Lei da Mediação, o Código de Processo Civil e a Resolução $n^{\circ}$ 125/2010 do CNJ, como visto, não é idêntica. O Quadro 1 ilustra bem tal fato.

\footnotetext{
${ }^{48}$ Art. 168. As partes podem escolher, de comum acordo, o conciliador, o mediador ou a câmara privada de conciliação e de mediação. $\S 1^{\circ} \mathrm{O}$ conciliador ou mediador escolhido pelas partes poderá ou não estar cadastrado no tribunal. $\S 2^{\circ}$ Inexistindo acordo quanto à escolha do mediador ou conciliador, haverá distribuição entre aqueles cadastrados no registro do tribunal, observada a respectiva formação. $\S 3^{\circ}$ Sempre que recomendável, haverá a designação de mais de um mediador ou conciliador. (BRASIL, 2015a)

${ }^{49}$ Lei da Mediação, art. $2^{\mathrm{a}}$, incisos I a VIII.

${ }^{50}$ Os princípios estão inseridos na Parte Geral, Livro III - Dos Sujeitos do Processo, Título IV - Do Juiz e dos Auxiliares da Justiça, Seção V - Dos Conciliadores e Mediadores Judiciais.

${ }^{51}$ Código de Processo Civil, art. 175.

${ }^{52}$ Código de Processo Civil, art. 175, parágrafo único.

${ }^{53}$ Código de Processo Civil, art. 166.

${ }^{54}$ Resolução CNJ no 125/2010, Anexo III, art. $1^{\text {o }}$.
} 
Os marcos normativos da mediação entre particulares no âmbito civil: escopo e relações de complementariedade, subsidiariedade e incompatibilidade

Quadro 1 - Distribuição dos princípios da mediação entre os atos normativos

\begin{tabular}{|c|c|c|}
\hline Lei da Mediação & Código de Processo Civil & Resolução no 125/2010 do CNJ \\
\hline Autonomia da vontade das partes & Autonomia da vontade & Autonomia \\
\hline Boa-fé & & \\
\hline Busca do consenso & & Competência \\
\hline Confidencialidade & Confidencialidade & Confidencialidade \\
\hline & Decisão informada & Decisão informada \\
\hline Imparcialidade do mediador & Imparcialidade & Empoderamento \\
\hline & Independência & Imparcialidade \\
\hline Informalidade & Informalidade & Independência \\
\hline Isonomia entre as partes & & Respeito à ordem pública e às \\
\hline Oralidade & Oralidade vigentes \\
\hline & & Validação \\
\hline
\end{tabular}

Fonte: elaborado pelos próprios autores.

Adicionando o rol de princípios da Lei da Mediação e rol de princípios do Código de Processo Civil referente à mediação, encontram-se aplicáveis à mediação judicial e extrajudicial os princípios da autonomia da vontade, da boa-fé, da busca do consenso, da confidencialidade, da decisão informada, da imparcialidade, da independência, da informalidade, da isonomia entre as partes e da oralidade. Por outro lado, existem princípios que foram previstos exclusivamente para a mediação judicial, como é o caso do princípio da competência, do empoderamento, do respeito à ordem pública e às leis vigentes e o princípio da validação, todos inseridos apenas na Resolução CNJ no 125/2010.

Esse cotejamento é relevante especialmente por permitir a percepção das implicações práticas dos diferentes posicionamentos a respeito das hipóteses de revogação de uma lei em relação às demais na disciplina da mediação.

Os princípios da mediação trazidos pela Resolução CNJ no 125/2010, pelo Código de Processo Civil e pela Lei da Mediação são estabelecidos em enunciados taxativos e muito parecidos ("São princípios fundamentais que regem a atuação de conciliadores e mediadores judiciais", "A conciliação e a mediação são informadas pelos princípios [...]" e "A mediação será orientada pelos seguintes princípios [...]", respectivamente). Diante de tal fato, as posições que defendem a ocorrência de pura e simples revogação dos dispositivos de uma lei por dispositivos de outra na disciplina da mediação devem concluir que permanecerão aplicáveis apenas os princípios da lei prevalecente. Em outras palavras, serão vigentes apenas os princípios do Código de Processo Civil ou apenas os da Lei da Mediação, mas não os princípios das duas leis simultaneamente. Posições que defendem a ocorrência de revogação tácita apenas nas hipóteses de incompatibilidades, tal como disposto no $\S 2^{\circ}$ do artigo $2^{\circ}$ da LINDB, concluem que os princípios dos 
três marcos normativos permanecem vigentes no âmbito de sua incidência, posto que são reciprocamente compatíveis.

\subsection{A obrigatoriedade da mediação}

A Lei da Mediação prevê expressamente que ninguém é obrigado a permanecer em procedimento de mediação ${ }^{55}$. Todavia, a questão de saber se a audiência inicial da mediação é ou não obrigatória tornou-se controversa em vários pontos. A previsão do Código de Processo Civil de que as partes podem abrir mão da mediação não se repetiu na Lei da Mediação. O próprio Código de Processo Civil também não repetiu essa possibilidade em outros dispositivos que prescrevem a mediação para situações específicas e não disciplinadas pela Lei da Mediação. Por fim, a Lei da Mediação trouxe disposições sobre a possibilidade de as partes acordarem previamente, em cláusula contratual, a opção pelo procedimento de mediação. Tais questões já deflagraram ou podem deflagrar divergências que, antes de superadas, precisam ser compreendidas a partir do escopo dos seus respectivos marcos normativos.

\subsubsection{A obrigatoriedade da audiência de mediação judicial}

O Código de Processo Civil estabelece que, na hipótese da "petição inicial preencher os requisitos essenciais e não for o caso de improcedência liminar do pedido, o juiz designará audiência de conciliação ou de mediação com antecedência mínima de 30 (trinta) dias, devendo ser citado o réu com pelo menos 20 (vinte) dias de antecedência" ${ }^{56}$ (BRASIL, 2015a). Todavia, o código não atribui caráter de obrigatoriedade a essa audiência de mediação. Tal audiência, além de não ser realizada em conflitos que não admitem autocomposição ${ }^{57}$, pode não se realizar quando todas as partes (inclusive os litisconsortes ${ }^{58}$ ) manifestarem expressamente desinteresse pela composição consensual ${ }^{59}$. $\mathrm{O}$ desinteresse do autor deve ser manifestado na petição inicial e o desinteresse do réu deve ser apresentado em petição avulsa com 10 dias de antecedência, contados da data da audiência ${ }^{60}$. Outro fato relacionado à obrigatoriedade da mediação no âmbito do Código de Processo Civil e que merece ser ressaltado diz respeito à redação do parágrafo $8^{\circ}$ do artigo 334. O enunciado do dispositivo estabelece que "o não comparecimento injustificado do autor ou do réu à audiência de conciliação é considerado ato atentatório à dignidade da justiça e será sancionado com multa de até dois por cento da vantagem econômica pretendida ou do valor da causa, revertida em favor da União ou do Estado". Como se lê, o código prevê que apenas a ausência injustificada à audiência de conciliação será sancionada, em nada disciplinando a ausência à audiência de mediação.

A Lei da Mediação, por outro lado, não repete a hipótese da audiência de mediação judicial ser dispensada pela vontade das partes. A Lei da Mediação enuncia apenas que o juiz designará audiência de mediação se a petição inicial preencher os requisitos essenciais e se não for o caso de improcedência liminar do pedido ${ }^{61}$.

\footnotetext{
${ }^{55}$ Lei da Mediação, art. $2^{\circ}, \S 2^{\circ}$.

${ }^{56}$ Código de Processo Civil, art. 334.

${ }^{57}$ Código de Processo Civil, art. $334, \S 4^{\circ}$, II.

${ }^{58}$ Código de Processo Civil. art. $334, \S 6^{\circ}$.

${ }^{59}$ Código de Processo Civil, art. $334, \S 4^{\circ}$, I.

${ }^{60}$ Código de Processo Civil, art. $334, \S 5^{\circ}$.

${ }^{61}$ Lei da Mediação, art. 27.
} 
Os marcos normativos da mediação entre particulares no âmbito civil: escopo e relações de complementariedade, subsidiariedade e incompatibilidade

Uma questão que pode ser suscitada dessa divergência entre o Código de Processo Civil e a Lei da Mediação é a de saber se a audiência de mediação judicial poderá ser descartada pela vontade das partes ou não. Como visto no tópico 2, algumas circunstâncias nas quais a lei não é clara o suficiente constituem zonas de indefinição que dão azo para várias interpretações e nenhuma pode ser descartada como ilegítima. A literatura jurídica pode sugerir soluções e o judiciário pode decidir como quiser até a matéria ser disciplinada de forma definitiva e vinculante.

Alguns autores entendem que a não repetição do enunciado do Código de Processo Civil significa uma revogação (DUARTE, 2015; RODOVALHO, 2015). De nossa parte, entendemos que não. Entendemos que a audiência de mediação judicial poderá ser cancelada pela vontade expressa das partes por algumas razões. Em primeiro lugar, porque entendemos que redação dos dois enunciados é compatível. Os enunciados do Código de Processo Civil (artigo 334, caput e $\S 4^{\circ}$, inciso I) são mais específicos nesse ponto que o enunciado da Lei da Mediação (artigo 27), apenas omisso. Entendemos que a Lei da Mediação se relaciona com o Código de Processo Civil tal como previsto no parágrafo $2^{\circ}$ do artigo $2^{\circ}$ da LINDB: a Lei da Mediação é uma lei nova que estabelece disposições gerais ou especiais a par das já existentes e não revoga nem modifica a lei anterior, o Código de Processo Civil. Casos semelhantes ao da obrigatoriedade da audiência de mediação ocorrem com a previsão de prazo de antecedência para a realização da audiência de mediação ${ }^{62}$ e com a sanção pelo não-comparecimento à audiência (que, repetimos, é prevista apenas para o caso de mediação). Como a Lei da Mediação é omissa nesse ponto ${ }^{63}$, defender que a Lei da Mediação revogou a possibilidade de as partes dispensarem a audiência de mediação apenas por não ter repetido o enunciado implica, por coerência, defender que o prazo mínimo de antecedência para a realização da audiência de mediação e a sanção para o não-comparecimento à audiência também foram revogados pela ausência de repetição de enunciado. Em segundo lugar, a Lei da Mediação não afastaria a incidência do artigo 190 do Código de Processo Civil, que permite que as partes plenamente capazes possam estipular mudanças no procedimento que envolva direitos que admitam autocomposição para ajustá-lo às especificidades da causa e convencionar sobre os seus ônus, poderes, faculdades e deveres processuais, antes ou durante o processo. Além dessas razões estritamente jurídicas, é possível argumentar em favor da não obrigatoriedade da audiência de mediação por um raciocínio utilitarista: forçar o comparecimento à audiência de mediação quando as partes não estão dispostas implica apenas desgastes e despesas desnecessárias, inclusive para o judiciário. Ademais, em qualquer fase processual posterior se poderá estimular os litigantes a tomarem uma solução autocompositiva.

\subsubsection{Obrigatoriedade da mediação judicial em litígio coletivo pela posse de}

\section{imóvel e em ações de família}

Existem outros dois casos específicos nos quais o Código de Processo Civil prescreve expressamente a realização da audiência de mediação também podem suscitar questionamentos quanto ao caráter obrigatório de tal audiência. Em linhas gerais, o artigo 565 prevê que o juiz, antes de apreciar o pedido liminar em litígio coletivo pela posse de imóvel, quando o esbulho ou a turbação afirmado na petição inicial houver ocorrido há mais de ano e dia, deverá designar audiência de mediação. O artigo 695, do mesmo modo, prevê que o juiz ordenará a citação do réu para comparecer à audiência de mediação e conciliação assim que receber a inicial e, se for o caso, decidir sobre a tutela provisória nas ações de família.

\footnotetext{
${ }^{62}$ Código de Processo Civil, art. 334.

${ }^{63}$ Lei da Mediação, art. 27.
} 
Em ambos os casos os enunciados não repetem a previsão do artigo $334, \S 4^{\circ}$, inciso I; isto é, não estabelecem expressamente que as partes podem evitar a audiência de mediação ao manifestarem desinteresse pela composição consensual. A indefinição quanto a obrigatoriedade da audiência de mediação nesses dois casos deriva do próprio Código de Processo Civil e não de sua relação com a Lei da Mediação. Tal como os enunciados estão redigidos, é possível argumentar tanto pela obrigatoriedade como pela não-obrigatoriedade. Caberá ao judiciário ou legislador estabilizar essa questão. De nossa parte, opinamos que a norma do artigo $334, \S 4^{\circ}$, inciso I, na qualidade de regra fundamental de procedimento, aplica-se aos casos especiais citados por ausência de disposição contrária expressa. O fato de não se repetir a possibilidade de as partes abrirem mão da audiência de mediação não significa que ela foi suprimida. Caso o entendimento contrário fosse procedente, a obrigatoriedade da audiência de mediação seria anulada pelo mesmo argumento: os artigos 565 e 695 não repetem a penalidade prevista no artigo $334, \S 8^{\circ}$ (que, repetimos mais uma vez, consideramos aplicável apenas na audiência de conciliação). Por fim, é relevante considerar que ações de família e possessórias não raramente comportam litigantes cuja aproximação não seria apenas dispensável, como também desaconselhável.

\subsubsection{A obrigatoriedade da mediação prevista em cláusula contratual}

A Lei da Mediação trouxe disposições sobre a obrigatoriedade da mediação prevista em cláusula contratual. Nesse caso, estabelece que as partes devem comparecer à primeira reunião ${ }^{64}$. Tal hipótese pode deflagrar divergências pelos mesmos motivos expostos nos subtópicos anteriores - as possíveis incompatibilidades entre a Lei da Mediação e o Código de Processo Civil.

No entanto, a obrigatoriedade de comparecer à primeira reunião de mediação, caso a mesma seja estabelecida em cláusula contratual, é plenamente compatível com as disposições do Código de Processo Civil, especialmente com a permissão dada às partes de manifestem desinteresse em autocomposição. Na prática, ao assinar contrato que em seus termos prevê a mediação, o que ocorre é que as partes já manifestam interesse pela audiência. Ademais, a audiência só não se realiza, em qualquer caso, quando todas as partes manifestarem desinteresse.

\subsection{O impedimento do mediador atuar como advogado}

A aplicação das mesmas hipóteses de impedimento e suspeição do juiz ${ }^{65}$ ao mediador é incontroversa. Ela é prescrita expressamente tanto o Código de Processo Civil ${ }^{66}$ como a Lei da Mediação ${ }^{67}$. Por outro lado, as disposições do Código de Processo Civil e da Lei da Mediação que dizem respeito aos impedimentos impostos especificamente aos advogados que atuam como mediadores não são isentas de problemas.

O Código de Processo Civil, em seu artigo 167, parágrafo $5^{\circ}$, estabelece que "os conciliadores e mediadores judiciais cadastrados na forma do caput, se advogados, estarão impedidos de exercer a advocacia nos juízos em que desempenhem suas funções”. A Lei da Mediação não repete essa previsão, mas estabelece um enunciado diferente sobre o impedimento para o mediador que for advogado. Nos termos do artigo $6^{\circ}$ da Lei da Mediação, "o mediador fica impedido,

\footnotetext{
${ }^{64}$ Lei da Mediação, art. $2^{\mathrm{o}}, \S 1^{\mathrm{o}}$.

${ }^{65}$ Código de Processo Civil, arts. 144 e 145.

${ }^{66}$ Código de Processo Civil, art. 148, II.

${ }^{67}$ Lei da Mediação, art. $5^{\circ}$.
} 
Os marcos normativos da mediação entre particulares no âmbito civil: escopo e relações de complementariedade, subsidiariedade e incompatibilidade

pelo prazo de um ano, contado do término da última audiência em que atuou, de assessorar, representar ou patrocinar qualquer das partes".

A percepção sobre qual das regras prevalece depende da mesma lógica adotada na compreensão das relações de complementariedade e incompatibilidade entre o Código de Processo Civil e a Lei da Mediação. Todavia, embora as normas disciplinem um mesmo tema, o conteúdo diverge em vários âmbitos. Em primeiro lugar, só o impedimento da Lei da Mediação alcança os mediadores que atuam em instâncias extrajudiciais. Em segundo lugar, o impedimento do Código de Processo Civil parece ter sido concebido como forma de evitar a captação de clientes e o impedimento da Lei da Mediação parece tentar evitar que o dever de confidencialidade seja desrespeitado. Constituem enunciados e impedimentos diferentes.

Existem opiniões que afirmam a revogação do impedimento previsto no Código de Processo Civil pelo enunciado da Lei da Mediação (LEI, 2015), mas, de nossa parte, entendemos que as duas hipóteses de impedimento funcionam autonomamente e simultaneamente. É um entendimento que já foi inclusive defendido pela $\mathrm{OAB} / \mathrm{SP}$, ainda que com acréscimo de um fundamento ligeiramente diferente ${ }^{68}$.

\subsection{A obrigatoriedade da presença de advogado na audiência de mediação}

Nesse último ponto, a Lei da Mediação e o Código de Processo Civil não se mostram incompatíveis. Os enunciados das duas leis disciplinam a matéria de forma inequívoca: a participação de advogado ou defensor público na mediação é obrigatória apenas para o procedimento judicial, enquanto no extrajudicial tal participação é facultativa desde todas as partes estejam desacompanhadas desses profissionais. Todavia, tendo em vista conclusões diversas (PL, 2016), parece relevante verificar os enunciados que disciplinam a questão.

O Código Processo Civil estabelece que as partes devem estar acompanhadas por advogados ou defensores públicos na audiência de mediação ou de conciliação judicial ${ }^{69}$. A Lei da

\footnotetext{
${ }^{68}$ EXERCÍCIO PROFISSIONAL - ADVOCACIA - MEDIAÇÃO E CONCILIAÇÃO - IMPEDIMENTOS ÉTICOS ENUNCIADO 47 DO II FONAMEC - TEMA QUE APRESENTA QUESTÕES DEONTOLÓGICAS - PARÂMETROS. Nas conciliações e mediações (processuais), que são realizadas perante os próprios Juízos, prevalecem não apenas os impedimentos legais (art. $6^{\circ}$ da Lei $\mathrm{n}^{\circ} 13.140 / 2015$ e art. 167, $\S 5^{\circ}$, do novo Código de Processo Civil), mas também os impedimentos éticos consagrados pela jurisprudência do TED I, de atuar ou envolver-se com as partes e questões conhecidas em decorrência de sua atuação no setor como, também, perante a Vara onde funcionou como conciliador. Quanto à conciliação/mediação (processual) feita perante os CEJUSCS, caso prevaleça o entendimento do Enunciado $\mathrm{n}^{\circ} 47$ do II FONAMEC e se, de fato, não houver vinculação do conciliador/mediador com determinado Juízo, sendo a conciliação/mediação realizada em local próprio, sem proximidade com os cartórios das varas, as razões do impedimento ético, que prestigiam a isenção e independência do advogado e buscam coibir a indevida captação de clientela, deixam de existir, ao menos em princípio, ressalvando-se a competência das Turmas Disciplinares para apurar eventuais infrações éticas dessa natureza. Prevalece, no entanto, o impedimento de advogar para as partes atendidas na conciliação/mediação e de exercer a advocacia perante o próprio CEJUSC no qual o advogado atuar como conciliador/mediador. Deve ainda o advogado pugnar para que as partes sempre estejam representadas por advogados e para que a organização dos CEJUSCS se dê mediante rodízio dentre os inscritos no respectivo quadro de conciliadores/mediadores e ofereça espaço próprio e distinto das salas dos magistrados e dos cartórios. Deve ainda pugnar pela dignidade e independência da advocacia. Em qualquer caso, o advogado que atuar como conciliador/mediador deve declinar claramente às partes sua profissão, os limites e impedimentos a que está sujeito e, ainda, que não exerce função decisória ou jurisdicional. Precedentes da Primeira Turma. E-3.444/2007, E-3.760/2009, E-4.331/2013, E-4.536/2015, E4.577/2015, E-4.614/2016, E-4.618/2016 e E-4.622/2016. Proc. E-4.669/2016 - v.u., em 16/06/2016, do parecer e ementa do Rel. Dr. FÁBIO DE SOUZA RAMACCIOTTI - Rev. Dr. GUILHERME MARTINS MALUFE - Presidente Dr. PEDRO PAULO WENDEL GASPARINI. (OAB/SP, 2016).

${ }^{69}$ Código de Processo Civil, art. 334, §9.
} 
Mediação, de igual modo, prescreve que as partes deverão ser assistidas por advogados ou defensores públicos, ressalvadas as hipóteses previstas nas Leis 9.099/1995 e 10.259/200170.

Sobre a obrigatoriedade da presença de advogado em mediação extrajudicial, o Código de Processo Civil nada disciplina. A Lei da Mediação, por outro lado, estabelece expressamente que a presença do advogado é facultativa ao enunciar que "as partes poderão ser assistidas por advogados ou defensores públicos" "71 (BRASIL, 2015b). Todavia, a Lei da Mediação estabelece ao mediador o dever suspender o procedimento quando apenas uma delas estiver acompanhada de advogado ou defensor público. Tal suspensão perdurará até que todas estejam igualmente $\operatorname{assistidas}^{72}$.

\section{CONSIDERAÇÕES FINAIS}

As controvérsias envolvendo a operacionalização da mediação não parecem desarrazoadas. Há bons motivos para os debates suscitados e boas justificativas para sustentar quaisquer posicionamentos em relação a uma ampla gama de aspectos desse instituto. Embora não tenha sido um componente que orientou a presente pesquisa, parece seguro concluir que a ausência de uma comunicação adequada entre os processos de elaboração das normas que disciplinam a mediação é a responsável por esse quadro de normatividade peculiar.

A Resolução no $125 / 2010$ do CNJ se justifica por ter sido pioneira na matéria e por ter o seu escopo voltado mais à estrutura e organização institucional que à disciplina da mediação. $\mathrm{O}$ Código de Processo Civil também se justifica por ter sido a primeira lei ordinária a ser publicada conferindo disciplina e procedimento específico à mediação entre particulares em matéria civil. Ela trouxe o necessário para que a mediação fosse operacional no âmbito jurídico sem esquecer dos procedimentos que funcionam em câmaras privadas. Ela e a resolução convivem muito bem. A Lei da Mediação, por outro lado, veio tímida e com uma vocação indefinida: disciplinou a mediação extrajudicial e a judicial sem revogar expressamente as disposições do Código de Processo Civil e sem substituí-lo por completo. Obviamente, a Lei da Mediação tem vários méritos, mas nenhum deles parece justificar a sua publicação como uma nova lei avulsa. Sua tramitação deveria ter sido apensada e processada como parte do Código de Processo Civil, preferencialmente. Caso essa alternativa não fosse viável, que ela trouxesse enunciados com revogações explícitas dos dispositivos do Código de Processo Civil.

Se esse quadro já não fosse suficientemente problemático, soma-se a isso o fato de a Lei da Mediação ter sido publicada depois do Código de Processo Civil e ter entrado em vigor antes dele. Isso jogou luz em mais outros problemas, dessa vez relacionados com a redação da Lei de Introdução às Normas do Direito Brasileiro que só poderiam ser percebidos adequadamente em circunstâncias tão atípicas quanto essa.

As exposições trazidas no presente artigo revelam que algumas divergências parecem ser apenas derivadas de leituras apressadas ou de incompreensões primárias que podem ser superadas facilmente, mas constatou-se a existência de outras que constituem verdadeiras aporias jurídicas. Embora os autores deste artigo tenham arriscado opiniões sobre a forma pela qual se pode compreender a relação dos marcos normativos que disciplinam a mediação, ficou claro que não se trata - e nem poderia se tratar - de um parecer definitivo. Dado que o convívio entre as normas que disciplinam a mediação não é pacífico e que até mesmo a aplicação da LINDB parece

\footnotetext{
${ }^{70}$ Lei da Mediação, art. 26.

${ }^{71}$ Lei da Mediação, art. 10.

${ }^{72}$ Lei da Mediação, art. 10, parágrafo único.
} 
Os marcos normativos da mediação entre particulares no âmbito civil: escopo e relações de complementariedade, subsidiariedade e incompatibilidade

controversa para resolver esses problemas, a principal e a mais segura conclusão a que se pode chegar é a de que caberá à prática judiciária ou ao próprio legislador assentar essas questões.

\section{REFERÊNCIAS}

BRASIL. Constituição (1988). Constituição da República Federativa do Brasil de 1988. Disponível em: <http://www.planalto.gov.br/ccivil_03/constituicao/constituicao.htm>. Acesso em: 01 set. 2016.

. Decreto $\mathbf{n}^{0}$ 1.572, de 28 de julho de 1995. Regulamenta a mediação na negociação coletiva de natureza trabalhista e dá outras providências. Publicado no Diário Oficial da União de 31 de julho de 1995. Disponível em <http://www.planalto.gov.br/ccivil_03/decreto/1995/D1572.htm>. Acesso em: 09 out. 2016.

. Decreto-Lei $\mathbf{n}^{\mathbf{0}} \mathbf{4 . 6 5 7}$, de 4 de setembro de 1942. Lei de Introdução às normas do Direito Brasileiro. Disponível em: $<$ https://www.planalto.gov.br/ccivil_03/decretolei/Del4657compilado.htm>. Acesso em: 09 out. 2016.

. II Pacto Republicano de Estado por um sistema de justiça mais acessível, ágil e efetivo. Publicado no Diário Oficial da União de 26 maio de 2009. Disponível em $<$ http://www.planalto.gov.br/ccivil_03/Outros/IIpacto.htm>. Acesso em: 02 mar. 2016.

. Lei $\mathbf{n}^{\mathbf{0}}$ 5.869, de 11 de janeiro de 1973. Institui o Código de Processo Civil (revogado pela Lei no 13.105, de 2015). Publicado no Diário Oficial da União de 17 de janeiro de 1973 e republicado em 27 de julho de 2006. Disponível em <http://www.planalto.gov.br/ccivil_03/leis/L5869impressao.htm>. Acessado em 01 out. 2016.

. Lei $\mathbf{n}^{0}$ 10.101, de 19 de dezembro de 2000. Dispõe sobre a participação dos trabalhadores nos lucros ou resultados da empresa e dá outras providências. Publicado no Diário Oficial da União de 20 de dezembro de 2000. Disponível em <http://www.planalto.gov.br/ccivil_03/leis/L10101.htm>. Acesso em: 5 out. 2016.

. Lei $\mathrm{n}^{\mathbf{0}} \mathbf{1 0 . 1 9 2}$, de 14 de fevereiro de 2001. Dispõe sobre medidas complementares ao Plano Real e dá outras providências. Publicado no Diário Oficial da União de 16 de fevereiro de 2001. Disponível em <http://www.planalto.gov.br/ccivil_03/leis/LEIS_2001/L10192.htm>. Acesso em: 01 out. 2016.

. Lei n⿳ 13.105, de 16 de março de 2015. Código de Processo Civil. Publicado no Diário

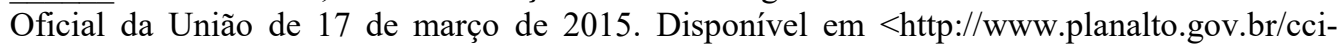
vil_03/_ato2015-2018/2015/lei/113105.htm>. Acesso em: 08 set. 2016.

. Lei no 13.140, de 26 de junho de 2015. Dispõe sobre a mediação entre particulares como meio de solução de controvérsias e sobre a autocomposição de conflitos no âmbito da administração pública. Publicada no Diário Oficial da União de 29 de junho de 2015. Disponível em < http://www.planalto.gov.br/ccivil_03/_Ato2015-2018/2015/Lei/L13140.htm>. Acesso em: 08 set. 2016

. CNJ. Resolução n ${ }^{\circ}$ 125, de 29 de novembro de 2010. Dispõe sobre a Política Judiciária Nacional de tratamento adequado dos conflitos de interesses no âmbito do Poder Judiciário e dá outras providências. Disponível em <http://www.cnj.jus.br/images/atos_normativos/resolucao/resolucao_125_29112010_11032016162839.pdf>. Acesso em: 01 set. 2016.

DONIZETTI, Elpídio. Curso didático de direito processual civil. 19. ed. São Paulo: Atlas, 2016. 
DUARTE, Zulmar. A difícil conciliação entre o Novo CPC e a Lei de Mediação. JOTA, 17 ago. 2015, artigos. Disponível em <http://jota.uol.com.br/a-dificil-conciliacao-entre-o-novo-cpc-e-alei-de-mediacao>. Acesso em: 11 out. 2016.

KELSEN, Hans. Teoria Pura do Direito. Trad. João Baptista Machado. 6. ed. São Paulo: Martins Fontes, 1998.

LEI da Mediação derruba restrições fixadas pelo CPC a advogados. Consultor Jurídico, São Paulo, 4 jun. 2015 Disponível em <http://www.conjur.com.br/2015-jun-04/lei-mediacao-derruba-restricoes-advogados-veja-texto>. Acesso em: 10 de outubro de 2016.

MINISTÉRIO DO TRABALHO E EMPREGO. Secretaria de Relações do Trabalho - SRT. Cartilha do Mediador. Disponível em <http://www3.mte.gov.br/sistemas/mediador/Content/docs/CARTILHA_DO_MEDIADOR_v20.pdf>. Acesso em: 10 out. 2016.

OAB/SP. Tribunal de Ética. 595 a Sessão de 16 de junho de 2016. Ementário - Turma de Ética Profissional, 16 jun. 2016. Disponível em <http://www2.oabsp.org.br/asp/tribunal_etica/pop_ementas.asp?tipoEmenta $=1 \& a n o=2016 \&$ id_sessao $=5 \&$ sequencial $=16>$. Acesso em: 17 out. 2016

PL torna obrigatória a participação de advogado na conciliação e mediação. Consultor Jurídico. São Paulo, 11 ago. 2016. Disponível em <http://www.conjur.com.br/2016-ago-11/pl-torna-obrigatoria-participacao-advogado-conciliacao>. Acesso em: 03 out. 2016.

RIBEIRO, Adriano da Silva. Mediação é o caminho para a solução de conflitos entre casais. Revista Consultor Jurídico, 27 out. 2008. Disponível em <http://www.conjur.com.br/2008-out27/mediacao_melhor_caminho_conflitos_entre_casais>. Acesso em: 01 out. 2016.

RODOVAlHO, Thiago. Mediação obrigatória? Portal Processual, 15 set. 2015, artigos. Disponível em <http://portalprocessual.com/mediacao-obrigatoria/>. Acesso em: 16 out. 2016.

SENADO FEDERAL. Ata da $1^{\text {a }}$ Reunião da Comissão de Juristas - Novo CPC, realizada em 30 de novembro de 2009. Diário do Senado Federal, Brasília, DF, ano LXV, nº 003, quarta-feira, 3 de fevereiro de 2010 - Brasília - DF. p. 545. Disponível em <http://legis.senado.leg.br/diarios $/$ BuscaDiario?tipDiario $=1 \&$ datDiario $=03 / 02 / 2010 \&$ paginaDireta $=545>$. Acesso em: 02 maio 2015.

. Projeto de Lei do Senado $\mathbf{n}^{\mathbf{0}}$ 517, de 2011 - Institui e disciplina o uso da mediação como instrumento para prevenção e solução consensual de conflitos. Disponível em $<$ http://legis.senado.leg.br/mateweb/arquivos/mate-pdf/95105.pdf>. Acesso em: 07 set. 2016.

STRECK, Lenio Luiz Streck; SARLET, Ingo Wolfgang; CLÈVE, Clemerson Merlin. Os limites constitucionais das resoluções do Conselho Nacional de Justiça (CNJ) e Conselho Nacional do Ministério Público (CNMP). Ministério Público do Rio Grande do Sul - MPRS. 2005. Disponível em $<$ http://www.mprs.mp.br/areas/atuacaomp/anexos_noticias/artigoimp.doc $>$. Acesso em: 28 set. 2016.

TARTUCE, Fernanda. Interação entre Novo CPC e Lei de Mediação: primeiras reflexões. Portal Processual, 30 jul. 2015, artigos. Disponível em $<$ http://portalprocessual.com/interacao-entrenovo-cpc-e-lei-de-mediacao-primeiras-reflexoes/>. Acesso em: 28 set. 2016.

THEODORO JÚNIOR. Humberto. Curso de Direito Processual Civil. Vol. I. 56. ed. Rio de Janeiro: Forense, 2015. 